International Journal of Advanced Educational Research

ISSN: 2455-6157

Impact Factor: RJIF 5.12

www.educationjournal.org

Volume 3; Issue 1; January 2018; Page No. 357-361

\title{
Development of the students vocabulary based on storybooks
}

\author{
Deviyani, Nuri Asni \\ University of Muslim Nusantara Al-Wasliyah, Indonesia
}

\begin{abstract}
Problems in this research is how the effectiveness of vocabulary development results based on storybooks on grade 5 students of SD Negeri 112279 Aekkanopan Kecamatan Kualuh Hulu Regency of North Labuhanbatu? The purpose of this study is to describe the effectiveness of the results of vocabulary development based on storybooks on grade 5 students of SD Negeri 112279 Aekkanopan Kecamatan Kualuh Hulu, North Labuhanbatu District. Research method used in this research is research development method (Research \& Development). The subject of research on the development of vocabulary based on book reading material is a validator. In addition, the subject of this research is a student V SD Negeri 112279 Aekkanopan Kecamatan Kualuh Hulu Labuhan Batu Utara. The object of research on this research is a picture book book that is implemented on grade V students of SD Negeri 112279 in improving vocabulary mastery. The instruments used to obtain this research data are test, observation and validation questionnaire. The results of this study indicate that the validation of experts on the design of vocabulary development based on story books obtained average score validation of 3.5 with good category. Thus, it can be concluded that the story book The Youngest worthy of use in the development of vocabulary grade V students Elementary School 112279 Aekkanopan Kecamatan Kualuh Hulu North Labuhanbatu regency. Furthermore, the effectiveness of vocabulary development result based on story book, which before the development process is in enough category and then increased to be good after development process on student of class V of SD Negeri 112279 Aekkanopan Kecamatan Kualuh Hulu Regency of North Labuhanbatu.
\end{abstract}

Keywords: development, vocabulary, storybook

\section{Introduction}

In the world of education, language is the basis for human knowledge. Similarly language teaching is the core and foundation for other subjects, especially for elementary school students. Indonesian language learning in elementary school (SD) aims to improve students' ability to communicate effectively, both orally and in writing with others in accordance with the context and situation. The role of teachers in this regard is very important, because to be able to develop language learning and achieve maximum results (Utami, 2014) ${ }^{[20] .}$

Be aware that learning the language will not be separated from learning vocabulary, vocabulary is the most important skills in language skills, without adequate vocabulary mastery, then the purpose of language learning will not be achieved, because the more vocabulary a person has, the more skilled he also speaks. Mastery of vocabulary is one of the main requirements that determine the success of a person to skill speak, the more rich the vocabulary of a person the more likely a person to skill speak and the easier it also convey and receive information either orally, writing, or using signs and signs (Utami, 2014) [20].

According Khomsah (2011) ${ }^{[7]}$ vocabulary is an important element in language activities related to the delivery of ideas or ideas by the speaker to the opponent to speak. It relates to a person's ability to capture or understand ideas or ideas conveyed by others. Vocabulary mastery greatly affects the language skills of a person, especially children aged 6-13 years who at this age the child has not much master vocabulary. It is important for the child to understand and learn the vocabulary, because the language skills of the child will increase as the quality and quantity of vocabulary increases.

According to Mulyati (2016) ${ }^{[9]}$ the vocabulary is also part of the language component. Vocabulary consists of words used in communication both orally and in writing. To be able to express the idea both orally and in writing requires proper selection of words. Someone who has a vocabulary mastery that is pretty much assumed no difficulty in putting ideas into writing. In order to obtain optimal vocabulary learning results, teachers need to equip students with words related to specific areas. Because in every field of science used special words. An improper debriefing may lead to incomplete student understanding of a science.

Furthermore, according to Khomsah (2011) ${ }^{[7]}$ children learn to master the vocabulary by trying to understand first things to say before saying. A child is more silent and notices the issues being discussed. The child will associate the vocabulary he hears with what happens after the speaker has finished saying something. When a child learns to speak, he hears first the vocabulary and sentence that others say. The vocabulary that the child learns is related to the processes, activities, objects and situations witnessed by the child. This means the child connects what is heard through the thought process. The systematic process of mastering the vocabulary experienced by children is called vocabulary mastery.

The development of the vocabulary of children is explained by Benedict (in Khomsah, 2011) ${ }^{[7]}$ that the child has mastered 
receptively 50 words at the age of about 13 months, but only at the age of about 19 months the child can productively spend 50 words. Furthermore Smith (in Khomsah, 2011) ${ }^{[7]}$ explains that the age between 2.5 and 4.5 years is the rapid development of vocabulary, 200-400 words dominated at the time. Children tend to create new words to fill the void if they forget or do not know the word they should be using. At the time of entering kindergarten, the child has mastered the vocabulary of about 8,000 words, and almost all the basic rules of grammar are mastered. Children can make sentences, negative sentences, compound sentences, and other constructs. However, during preschool the child has difficulty regarding passive sentences. Harwood (in Khomsah, 2011) ${ }^{[7]}$ explains that up to the age of 5.5 years, the child has not fully grasped passive construction: he did not find a passive sentence while observing about 12,000 spontaneous sentences spoken by a 5year-old child.

The relatively limited ability of vocabulary mastery, in terms of quantity quality, will be an obstacle in expressing ideas and ideas systematically and logically. According Moelyono (in Khomsah, 2011) [7] sometimes communication can run effectively though with a very limited vocabulary. In language life the vocabulary problem is continuously reproduced, expanded, given the increasing importance of Indonesian language both in terms of form and its meaning. Vocabulary mastery is not a simple matter, for the reason that vocabulary is already known in everyday life. Vocabulary mastery can be influenced by background knowledge, age, and education as well as the number of references.

The importance of vocabulary learning on improving and developing the ability of language students leads to vocabulary learning increasingly urgent to be done more seriously and directed. This is due to the fact there are still many students who have difficulty in learning Indonesian language. This difficulty is especially evident when learning four language skills caused by the low level of Indonesian vocabulary skills. Hurlock (2009: 153) suggests that the vocabulary that must be controlled by children aged 6-13 years or elementary students there are two types, namely the general vocabulary and special counseling. General vocabulary, including common words that humans use to communicate, ie verbs, nouns, adjectives, adverbs, couples or pronouns. Unlike the general vocabulary, special vocabulary is a special word that covers certain things like time vocabulary, color, money, secret vocabulary, popular vocabulary, and vocabulary.

Based on the results of research conducted by Pramesti (2015)

[12] that elementary school students (SD) still difficulty in mastering vocabulary. The problem of low vocabulary in Indonesian language not only affects the students' disability in one skill, but furthermore, the low mastery of Indonesian vocabulary also influences all other language skills. Thus, low vocabulary mastery can negatively impact students' ability to read, write, talk and listen. Therefore, the mastery of Indonesian vocabulary for elementary school students (SD) requires facilities or media that can support the development of vocabulary students.

Student vocabulary development through storybooks accompanied by images provides a pre-reading experience in children, reading stories that are very useful to evoke positive feelings of the child. Children can "enjoy" the contents of a book when read aloud. It is this positive feeling that will encourage the child to master the book more quickly so that his interest in books as the primary device of reading grows dynamically (Adhim, 2010: 91) ${ }^{[1]}$. Furthermore, according to Musforih (2008: 94) the story book to be an effective stimulation for children, because at that time interest in reading in children began to grow. That interest should be given the right land, among others through the activities of story telling. Reading stories can provide an effective example for children how to read activities to do. Indirectly, the child gets an example of a person who likes and is smart to read from what he sees. If you often get an example, the interest in reading children will grow and voluntarily. The child will learn to identify the symbols of writing in a series of words and in sentences.

The story book with the picture is a good learning media to stimulate children to read. The striking colors will stimulate the interest of the child to read as well as arouse his curiosity. This is a very valuable stock. For children who have never known letters at all, colorful book packaging makes it easy for children to learn. Meanwhile, for children who already have pre-reading experience at an earlier age, storybooks can increase their interest in learning to read, so by reading children's stories, students will indirectly develop their vocabulary.

\section{Method}

The subject of research on the development of vocabulary based on book reading material is a validator. Assessment is done by filling the validation sheet that has been provided, which became the validator in this study is an expert lecturer. In addition, the subject of this study are students V SD Negeri 112279 Aekkanopan Kecamatan Kualuh Hulu district of Labuhan Batu Utara, North Sumatra Province of Indonesia. The object of research on this research is a picture story book that is implemented in grade 5 students of SD Negeri 112279 in improving vocabulary mastery.

Instruments used to obtain research data using test instruments, observation sheets and expert validation sheet. The test instrument used is a vocabulary test. The observation sheet is used to determine the students' vocabulary development while the expert validation sheet is used to find out the validation result done by the expert on developing the vocabulary of the students based on the reading of the story book.

Data collection techniques in this study using observation techniques, questionnaires and validation sheet. The test is used to obtain data about vocabulary mastery of students before and after the development of vocabulary based on story books. Technique of collecting data in the form of observation done during teaching learning process by using story book to get data about student vocabulary development. Observations made by the researchers themselves. The validation sheet is given to the expert lecturer. The validation sheet contains an explanation given by the validator about the feasibility of reading material used in developing student vocabulary.

\section{Result}

The process of designing vocabulary development based on 
storybook in grade V students of SD Negeri 112279 Aekkanopan Kecamatan Kualuh Hulu of North Labuhanbatu Regency consists of several stages, namely requirement analysis phase, data collection and product design design. Needs analysis phase is done by observation and test. From the observation of the learning that the researcher did show that the teacher only introduced the opposite words and equations of words (synonyms and antonyms), the students were asked to search and find the equations of a word, then copy in the notebook, and count the many words written. But the reality in the field in the implementation of learning that occurs, the learning is still conventional, namely the implementation of teacher-centered learning, based on teacher handbook material so that students are less active, and not confident, and less creative and have not utilized various media as a source of learning.

From the results of observations of researchers on the course of the learning process found some conditions that need to be followed up for the sake of refinement, among others:

1. Teacher learning step less systematic.

This is because teachers in teaching are not guided by a lesson plan prepared before teaching. When teachers start learning, the teacher has not explained the goals / indicators to be mastered by the students. This needs to be conveyed to the teacher even though verbally. That way at least the students will understand what they have to accomplish. Teacher-centered learning. Teachers have not been able to develop and use various learning media so that students are active in learning activities.

2. There is still a lack of utilization of learning media and variation of methods by teachers.

The lecture method becomes the teacher's primary choice and dominates learning. The student's active role is only visible when they respond together when asked by the teacher. So than it is necessary to do learning innovation. With so created a fun learning atmosphere. Learning in a fun atmosphere will be easy to accept and the ability that is expected to be easily achieved.

3. Opportunities and concerns for impotent children in the management of learning are still ignored.

That is, when teachers hold group work, teachers have not set up a seat that allows children to work freely. All group members are in a row of seats. So, the child sitting on the edge is not very clear with the task to be done. As a result, this child lacks the opportunity to complete the task. Plus they are children who still have difficulty in understanding the meaning of a word. Meanwhile, clever children in one group, will dominate the work. While the child who is busy working is not free because he was sitting in the middle and pressed by other friends. This situation sometimes cause displeasure in children. Children who work the task to feel themselves capable, while the less clever children feel inferior because he does not understand. Such circumstances clearly do not support the learning process in children. Therefore, group formation needs to be arranged in such a way that when a child's working group of children can see the tilis board, see the teacher, and see the friends of the group members to communicate.

Teachers do not give opportunities to children who are less clever. That is, children who are less clever are not given the opportunity to do. They just sit and look. Instead this should not be too long left. Teachers should give direction to children who are smarter to give opportunities and help to friends who can not be like himself. Thus there is an interaction between students and students. They share knowledge and experience. Children who are less clever may have difficulty in understanding the meaning / meaning of a word. But if the opportunity is there, and other friends want to help, coupled with the guidance of teachers then little by little the child progress and difficulty can be overcome.

4. The students' happiness has not been maximally developed.

Many study materials were taken from the teacher's handbook. This is done by the teacher because when trained students' knowledge about vocabulary all the students do not have handbook of student / material, students pay attention to teacher and book desired by teacher.

From the conditions found by researchers in the process of learning this vocabulary can be concluded, during this learning is still centered on the teacher. Teachers are still lacking in the use of varied media and methods that can create a conducive, more lively and enjoyable learning environment. Services and attention of teachers in children, especially those who have difficulty still felt less. The child does not have any experience on the meaning / meaning of the word.

Based on this, it is necessary to strive for learning innovation in order to optimize the participation of students so that it is active and productive, creating a learning atmosphere full of spirit and achieving meaningful learning outcomes for students. After the observation is done, the next step is to provide a vocabulary test. This test is given as a first step (pre-test) to know the mastery of vocabulary students before using the story book.

\section{Discussion}

Preliminary research results indicate that the test results of vocabulary mastery are included in the category enough. The problem indicates that students need individual learning materials that are useful for improving students' vocabulary mastery. To solve the problem, the researcher develops vocabulary based on story book as the material that will be developed.

Mastery of vocabulary of students before the development described above is the basis used by researchers to develop students' vocabulary based on storybooks. Researchers develop vocabulary through story books based on data that has been found that is the result of initial observation and test results. Development of vocabulary of students based on story books that is by using the story book $\mathrm{Si}$ Youngest folklore from Riau ..

The purpose of this development is that students are able to master the vocabulary. In addition, this story book was developed in order to improve students' vocabulary mastery. Researchers make this development by considering several aspects such as the needs of students in the use of learning 
materials, situations and conditions, learning resources used. Based on the results of research on the validation test results conducted by Mr. Prof. Dr. Khairil Ansari, M.Pd., showed that on the aspect assessed obtained the average validation score of 3.5 with good category. Thus, it can be concluded that the story book The Youngest worthy of use in the development of vocabulary grade V students Elementary School 112279 Aekkanopan Kecamatan Kualuh Hulu North Labuhanbatu regency.

In addition, the results of this study were also supported by the responses expressed by students after the product test obtained an average score of $4.6 \%$ which fall into the category very well. Thus, it can be concluded that the story book The Youngest worthy as a learning material vocabulary mastery in class V SD Negeri 112279 Aekkanopan Kecamatan Kualuh Hulu North Labuhanbatu regency.

Based on the results of calculations that researchers have done, shows that the average value of mastery of vocabulary obtained by students before the development process based on story books that is equal to 68.28 . Thus, the average level of vocabulary mastery of grade V students of SD Negeri 112279 Aekkanopan Kecamatan Kualuh Hulu of North Labuhanbatu before the development process can be said enough.

Furthermore, after the process of development and implementation of the story book The Youngest shows that the average value of vocabulary mastery owned by students that is equal to 78.85 . Thus, the average level of vocabulary mastery of grade V students of SD Negeri 112279 Aekkanopan Kecamatan Kualuh Hulu North Labuhanbatu Regency after development can be said good. It is also supported by observation result, which got the value of observation after development that is equal to $79,05 \%$ enter in good category. From these results, it appears that the storybook Si Youngest effective in improving the mastery of vocabulary grade V SD Negeri 112279 Aekkanopan Kecamatan Kualuh Hulu North Labuhanbatu regency, where before the development process is in the category enough and then increased to be good after the development process in class V SD Negeri 112279 Aekkanopan Kecamatan Kualuh Hulu Regency of North Labuhanbatu.

\section{Conclusion}

Based on the result of the research, it can be concluded that:

1. Vocabulary development based on storybook in grade $\mathrm{V}$ students of SD Negeri 112279 Aekkanopan Kecamatan Kualuh Hulu of Labuhanbatu Utara Regency begins with information related to student description in learning implementation in class, it is known that learning has been well implemented. However, students' responses to both material and learning evaluations are low. Based on the collection of information obtained, obtained the results that required the development of vocabulary mastery of students is by using the story book $\mathrm{Si}$ Youngest.

2. Expert validation results on the development of vocabulary design based on the story book obtained the average validation score of 3.5 with good category. Thus, it can be concluded that the story book The Youngest worthy of use in the development of vocabulary grade $\mathrm{V}$ students Elementary School 112279 Aekkanopan
Kecamatan Kualuh Hulu North Labuhanbatu regency.

3. The effectiveness of the results of vocabulary development design based on the story book, which before the development process is in enough category and then increased to be good after the development process on the students of class V SD Negeri 112279 Aekkanopan Kecamatan Kualuh Hulu Regency North Labuhanbatu.

\section{References}

1. Adhim, Masri. Menumbuhkan Minat Baca Sejak Dini. Jakarta: Macanan Jaya Cemerlang. 2010.

2. Annisa. Peningkatan Penguasaan Kosakata dengan Media Wall Chart pada Siswa Kelas 1 SD N 05 Bangsri Kabupaten Jepara. Jurnal Pendidikan Universitas Negeri Semarang. 2011.

3. Arikunto S. Prosedur Penelitian Suatu Pendekatan Praktik. Jakarta: Rineka Cipta. 2010.

4. Chaer, Abdul. Dasar-dasar Linguistik Umum. Jakarta : Rineka Cipta 2010.

5. Chaer, Abdul. Tata Bahasa Praktis Bahasa Indonesia. Jakarta: Rineka Cipta 2010.

6. Febylia Sukanda. Pengembangan Media Buku Cerita Bergambar Tema Pekerjaan untuk Meningkatkan Pengetahuan Karir Siswa Kelas IV Sekolah Dasar. Universitas Negeri Surabaya. Jurnal Pendidikan. 2014.

7. Khomsah, Arin Nur. Peningkatan Penguasaan Kosakata melalui Media Pass Picture dengan Menggunakan Metode Permainan Kata pada Siswa Kelas B-2 TK Kartika III-20 Srondol Semarang. Jurusan Bahasa dan Sastra Indonesia. Fakultas Bahasa dan Seni. Universitas Negeri Semarang 2011.

8. Mardika, I Nyoman. Pengembangan Multimedia Dalam Pembelajaran Kosakata Bahasa Inggris di SD. Pamong Belajar SKB Donggala. 2015.

9. Mulyati, Sri. Pengaruh Penguasaan Kosakata Dan Tata Bahasa Terhadap Menulis Bahasa Inggris. Jurnal ABA BSI Jakarta. Wanastra Vol IX No. 2 September 20162016.

10. Nurgiyantoro, Burhan. Statistika Terapan: Untuk Penelitian dan Ilmu-ilmu Sosial. Yogyakarta: Gadjah Mada University Press. 2010.

11. Nurgiyantoro, Burhan. Penilaian Pembelajaran Bahasa Berbasis Kompetensi. Yogyakarta: BPFE. 2012.

12. Pramesti, Utami Dewi. Peningkatan Penguasaan Kosakata Bahasa Indonesia Dalam Keterampilan Membaca Melalui Teka-Teki Silang. Universeitas Negeri Padang. Jurnal Puitika 2015;11(1), April 2015.

13. Ratri, Rizky Pramudyas, dkk. Analisis Pengembangan Kosakata Siswa Kelas V SDN 02 Gunungreja Melalui Membaca Cerita Anak. Jurnal Pendidikan. Universitas Pendidikan Indonesia Kampus Tasikmalaya 2015.

14. Rinawati. Hubungan Penguasaan Kosakata dengan Kemampuan Mengarang Dongeng Siswa Kelas V SD di Kecamatan Pakualaman Yogyakarta. Jurnal Pendidikan. Universitas Negeri Yogyakarta. 2014.

15. Rita Eka Izzaty, dkk. Pengembangan Buku Cerita Tematik Sebagai Media Pembelajaran Pengenalan Membaca Pada Anak Pra Sekolah. Laporan Akhir Penelitian Unggulan Universitas Negeri Yogyakarta. 2014. 
16. Sapta A, Marchi RF. The Development of Modelling The Way Learning In The Course of The Mathematics Curriculum of Junior High School. 2014.

17. Sugiyono. Metode Penelitian Kuantitatif dan R \& D. Bandung: ALFABETA. 2010.

18. Susanto, Hadi. Membangun Minat Baca Anak Usia Dini Melalui Penyediaan Buku Bergambar. Makalah. Malang: Perpustakaan UM. 2011.

19. Unsi, Baiq Tuhfatul. Media Gambar Dalam Pembelajaran Kosakata Bahasa Arab. Fakultas Tarbiyah dan Keguruan Isntitut Agama Islam Bani Fattah Jombang. Tafaqquh; 2014;2(1), Juni 2014

20. Utami, Desiana Wahyu. Peningkatan Penguasaan Kosakata Bahasa Indonesia Melalui Media Papan Selip (Slot Board) Pada Siswa Kelas II SDN 2 Karangtalun Tahun 2013/2014. Naskah Publikasi. Universitas Muhammadiyah Surakarta. 2014.

21. Wigianto. Pengembangan Buku Cerita Bergambar Pendidikan Karakter Tanggung Jawab Untuk Peserta Didik Sekolah Dasar. Universitas Negeri Yogyakarta. EJournal. 2015. 